\title{
PENANGGUNGJAWAB PENDIDIKAN
}

\author{
SYAMSUL QAMAR \\ Fakultas Tarbiyah dan Keguruan \\ Universitas Islam Negeri Alauddin Makassar
}

\begin{abstract}
:
Education is a conscious and planned effort to create an atmosphere of learning and learning process so that learners actively develop their potential to have religious spiritual power, self-control, personality, intelligence, noble character and skills needed for him, nation society and country. The ideas mentioned above will only be implemented if education is really well implemented by those mandated to pursue such education, among others; parents, educators, community and government. With respect to education responsibilities, parents should be responsible for the implementation of education in the household, educators responsible for the ongoing education in schools/universities and the government is responsible for the implementation of the national education process.
\end{abstract}

Keywords: Education, Responsibility

\section{PENDAHULUAN}

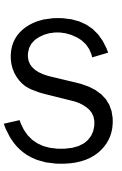

oal pertumbuhan pendidikan nasional yang mengalami akselerasi terutama pada dekade 1990-an, Indonesia perlu berbangga. Laporan studi Missi Bank Dunia (World Bank Report) dalam pelaksanaan Education for All (Pendidikan Bagi Semua), terutama menyangkut Pemberantasan Buta Aksara dan Universalisasi Sekolah Dasar menyebutkan bahwa Indonesia termasuk satu di antara 30 negara dari 150 negara berkembang yang dipandang telah berhasil mencapai sasaran pelaksanaan program Universalisasi Sekolah Dasar dengan capaian 95 \% anak usia 7-12 tahun bersekolah (Bank Dunia, 1996). Keberhasilan itulah yang mendorong pemerintah mencanangkan perpanjangan waktu belajar, dari 6 tahun sekolah dasar menjadi 9 tahun pendidikan dasar (Wajar 9 tahun) yang meliputi 6 tahun Sekolah Dasar (SD) dan 3 tahun Sekolah Lanjutan Tingkat Pertama (SLTP).

Namun pendidikan bukan soal pertumbuhan, pemerataan dan akselerasi semata. Mutu hasil belajar dan efisiensi pelaksanaan pendidikan nasional hingga kini belum menunjukkan tingkat percapaian yang menggembirakan. Masih rendahnya mutu hasil belajar, tingginya tingkat drop out di SD dan SLTP, kesenjangan antara sekolah dan realitas dunia kerja, dan kurikulum yang sentralistik dan "serba sama" dari Jakarta hingga Papua merupakan contoh bahwa pendidikan nasional belum mendapat perhatian serius. Ditambah lagi dengan model pengajaran selama ini yang konservatif dan verbalistik di mana anak-anak hanya disuapi dengan seperangkat informasi dari otak ke otak (transfer of head) tanpa membangun karakter (character building) yang bersendikan nilai-nilai 
agama, budaya dan susila (transfer of values) (Analisis CSIS, 1990). Dalam kondisi demikian ini, wajar kalau ada tudingan bahkan statemen-statemen "telanjang" bahwa (institusi) pendidikan hanya melahirkan anak muda yang "pintar" (secara kognitif), tetapi tidak cerdas dan peka terhadap masalah-masalah yang terjadi di sekitarnya (Mastuki, 2001:101).

Memang pendidikan merupakan suatu keharusan bagi manusia, sebab hanya melalui proses pendidikan, manusia itu dapat menjadi manusia seutuhnya. Dengan pendidikan, manusia dapat mengkomunikasikan kebudayaan, peradaban dan warisan intelektualnya kepada generasi berikutnya serta memberikan inspirasi citacita hidupnya (Robith, 1992:13).

Pernyataan di atas memberikan makna dan asumsi bahwa dalam melakukan transformasi nilai-nilai yang dibawa dan dikembangkan, manusia harus melalui proses pendidikan yang sistematis. Hal ini dikarenakan di dalam pendidikan itulah terdapat sejumlah pesan kultural dan akademis yang harus diolah dan diserap oleh manusia.

Secara para ahli memberikan definisi tentang pendidikan yang pada substansinya menurut terwujudnya program berjenjang, gradual dan terarah melalui peningkatan kegiatan pendidikan dan pengajaran yang membawa peserta didik dari suatu perkembangan ke perkembangan lainnya (al-Nahlawi, 1995:21).

Guna mengimplementasikan sejumlah konsep di atas, diperlukan seperangkat penunjang pendidikan yang satu sama lain menjadi suatu kesatuan sistem demi berlangsungnya proses yang diharapkan. Seperangkat sistem yang dimaksudkan adalah penanggungjawa pendidikan, tenaga pengajar, peserta didik, metode, media, materi dan lingkungan pendidikan.

Pendidikan akan berjalan dengan baik jika para penanggungjawab pendidikan melaksanakan dan memahami status, peran dan fungsinya dalam dunia pendidikan. Penanggungjawab pendidikan memiliki peran utama dalam melangsungkan proses pembelajaran, baik di sektor formal, informal maupun nonformal.

Siapa saja yang termasuk dalam penanggungjawab pendidikan? Pertanyaan inilah yang akan dijawab di dalam makalah ini dengan rumusan masalah sebagai berikut: (1) Siapa yang bertanggungjawab atas berlangsungnya proses pendidikan; (2) Apa tugas dan peranan penanggungjawab pendidikan dunia pendidikan?

\section{PENANGGUNGJAWAB PENDIDIKAN ORANG TUA}

Supaya pendidikan berjalan dengan baik, maka penanggungjawab pertama dan utama bagi anak didik di dalam keluarga adalah orang tua (Nawawi, 1993:85), sebab di dalam rumahlah anak pertama kali mengenal nilai dan interaksi edukatif dan kultural. 
Islam mengajarkan bahwa pendidikan itu berlangsung seumur hidup (life long education), dari buaian ke liang lahat (Hadits Nabi). Konsep pendidikan seumur hidup menegaskan bahwa pendidikan di dalam keluarga mesti dilakukan. Maka dari itu, orang tua wajib menjadi penanggungjawab berlangsungnya pendidikan di dalam keluarga sehingga usaha mencerdaskan anak baik emosional, intelektual dan spiritual dapat terjamin dengan baik.

Orang tua sebagai penanggungjawab pendidikan memiliki peranan yang sangat dominan di dalam proses pendidikan. Antara orang tua dan anak memiliki hubungan emosional dan interaksi edukatif yang intensif yang dapat menciptakan atmosfer pendidikan. Maka dari itu, Zakiah Darajat menekankan bahwa kondisi jiwa orang tua, hubungan antara satu dengan yang lainnya harus benar-benar mencerminkan figur pendidik yang memiliki tanggung jawab besar terhadap keluarganya (Daradjat, 1982, 65).

Sebagai penanggungjawab, orang tua memiliki kedudukan yang instimewa di mata anak-anaknya. Karena orang tua memiliki tanggung jawab yang besar dalam mempersiapkan dan mewujudkan masa depan anak-anaknya, mereka dituntut untuk berperan aktif dalam membimbing dan mendidik anak-anaknya.

Sayyid Qutb memberikan syarat utama kepada orang tua sebagai penanggungjawab pendidikan yaitu moralitas dan semangat keagamaan yang harus tercermin dalam setiap perilaku dan perkataannya, sebab menurut Qutb, orang tua harus menjadi panutan bagi anak-anaknya. Biasanya anak cepat meniru atau mencontoh apa yang diucapkan atau diperbuat orang tua di rumah tangga (Qutb:101). Lebih jauh menurt Saifuddin, keluarga merupakan lingkaran sekolah utama dan pertama bagi anak yang mendasari jenjang-jenjang pendidikan selanjutnya (Saifuddin, 1987:130).

Menurut Yusuf Barmawi, sebagai penanggungjawab, orang tua berdosa jika tidak mengemban amanah pendidikan ini, minimal ia memberikan perhatian yang cukup terhadap proses pendidikan anaknya. la tidak saja dapat menyekolahkan melalui pendidikan, tetapi ia juga harus berperan sebagai guru pertama yang memberikan keteladanan, mengarahkan anaknya dalam menentukan masa depan dan lain-lain (Barmawi, 1993:17).

Dengan menyadari dirinya dan melaksanakan tugasnya sebagai penanggungjawab, maka orang tua telah memuliakan anak-anaknya. Hal ni seirama dengan perintah Rasullah dalam sabdanya (Ibnu Majah:1221):

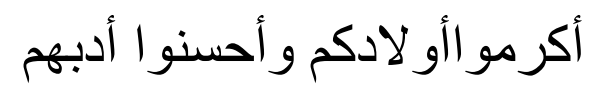

Sebagai penanggungjawab, orang tua tidak boleh membiarkan pertumbuhan anak berjalan tanpa bimbingan atau diserahkan kepada guru-guru di sekolah. Inilah menurut Zakiyah Darajat kekeliruan fatal yang banyak di dalam masyarakat (Darajat, 1982:47). 
Lalu apa tugas utama orang tua sebagai penanggungjawab pendidikan jika merujuk kepada al-Qur'an? Secara tegas al-Qur'an dalam surat Luqman 12-19 memberikan gambaran tugas orang tua sebagai penanggungjawab pendidikan dalam keluarga.

Secara terperinci tugas dan tanggungjawab orang tua dalam pendidikan tersebut adalah;

\section{Menanamkan Aqidah}

Aspek akidah merupakan aspek fudamental yang harus ditanamkan kepada anak sejak dini, sebab akidah dapat memberikan bimbingan secara moral dan sosial kepada anak. Menurut Abdullah 'Ulwan, di antara tugas sebagai penanggungjawab pendidikan di rumah tangga, orang tua harus memberikan petunjuk dan mengajari anak tentang keimanan kepada Allah secara bertahap dari penginderaan akal kepada fenomena, dari parsial menuju kepada yang integral, dari yang paling sederhana kepada hal yang kompleks (Ulwan, 1981:162).

Konsep keimanan kepada Allah tidak hanya dipahami sebagai konsep dasar tentang ketauhidann, tapi lebih jauh adalah aplikasinya dalam kehidupan anak sebagai way of Ife, bukan sebatas norma dan dogmatis. Sudah menjadi tanggung jawab orang tua menerangkan kepada anak-anak tentang prinsip-prinsip agama serta hukum agama sehingga anak benar-benar mengerti tentang pengalaman dan pengalaman dalam beragama (Langgulung,1989:381).

Implikasi penanaman akidah ini akan berdampak pada karakter dan moralitas anak sebab akhlak itu sendiri merupakan bagian dari agama. Menurut Ismail Ali, barang siapa yang bertambah baik akhlaknya, maka baik pula agamanya (Ali, 1978:173).

\section{Menanamkan Nilai Sosial}

Kehidupan sosial, cepat atau lambat selalu mengalami perubahan dan perkembangan di berbagai sektor kehidupan. Perubahan itu dan menimbulkan berbagai kebutuhan di semua aspek (Muhaimin, 1993:59), yang mengharuskan kita mengambil sikap dan mengaktualisasikan peran di dalamnya. Untuk itulah, sebagai penanggungjawab pendidikan, orang tua memiliki fungsi dan peran strategis dalam mensinergikan perubahan sosial beserta nilanya dengan perkembangan anak didik di rumah tangga.

Sebagai penanggungjawab, al-Qur'an sebagaimana terdapat dalam Q.S. Luqman, menyuruh orang tua berperan aktif dalam kesadaran sosial, mengajarkan anak bagaimana seharusnya berbuat baik kepada manusia dengan konsep "Amar Ma'ruf dan Nabi Munkar". Al-Quran senantiasa mengingatkan manusia memiliki kepedulian terhadap lingkungan sosial, sayang dengan alam, tidak angkuh dan sombong di depan manusia. Konsep al-Qur'an semacam ini selayaknya direalisasikan dalam pendidikan awal anak-anak di rumah tangga. 
3. Membina Perkembangan Fisik, Psikis dan Intelektual

Setiap orang tua harus berupaya agar anak-anaknya tumbuh secara wajar dan baik, lepas dari berbagai ikatan, tekanan batin dan jiwa, supaya mereka merasakan ketenangan, kesenangan dan kesejukan dalam mengikuti irama perkembangan dan pertumbuhannya sehingga mereka merasakan kebahagiaan hidup bersama orang tuanya (Ayyub, 1994:313).

Sebagai penanggungjawab utama dalam pendidikan keluarga, orang tua harus memperhatikan perkembangan fisik anak, sebab ini juga akan berpengaruh terhadap perkembangan lainnya.

Orang tua, sebagaimana disinggung dalam Q.S. Luqman, berkewajiban memberikan makanan yang halal dan bergizi (al-Quran), agar anak-anak sehat dan terhindar dari penyakit. Air susu, misalnya, memiliki pengaruh bukan semata pada persoalan fisik, tetapi lebih jauh memiliki pengaruh yang cukup signifikan terhadap perkembangan psikis. Menurut Ahmad Tafsir, secar psikis, ASI (Air Susu Ibu) itulah yang paling baik buat anak-anak, sebab di saat ibu menyusui, sebenarnya ia sedang mencurahkan kasih sayang kepada anaknya (Tafsir, 1992:171). Lebih jauh Khairiyah Husain Taha mengemukakan bahwa menyusui merupakan kerja psikis dan fisik yang memiliki peranan dan pengaruh yang amat besar bagi pertumbuhan fisik, mental dan kepribadian anak (Taha, 1994:57).

\section{TENAGA PENDIDIK}

Sama halnya dengan orang tua, tenaga pendidik juga memiliki tanggungjawab atas berlangsungnya proses pendidikan dan pengajaran. Oleh karena itu, pada hakekatnya tenaga pendidik tersebut merupakan orang tua dan sesudah orang tua kandung.

Sebagaimana halnya orang tua, para pendidik selalu beradal dalam proses interaksi edukatif dalam lingkungan pendidikan. la memiliki kedudukan dan peran sentral dalam proses pembelajaran, terutama di sekolah, bahkan irama interaksi edukatifnya sengaja didesain sedemikian rupa, sistematis dan metodologis dalam rangka mempermudah peserta didik dan meyerap ilmu yang diberikan.

Tanggungjawab tenaga pendidik tidak saja terikat pada tugas formalnya saja, tetapi di luar dari kerja kewajibannya, sesungguhnya ia masih dituntut memikukl tanggung jawab tersebut. Oleh karena besar dan beratnya tanggung jawab yang dipikul hingga mereka mendapat sebutan "Pahlawan Tanpa Tanda Jasa”, sebuah ungkapan yang menurut hemat penulis perlu direvisi kembali.

Tenaga pendidik, dengan segala tugas dan fungsinya bertanggungjawab dalam pembentukan dan pembinaan intelektualitas peserta didik di samping pembinaan aspek lainnya. Yang dimaksud dengan pendidikan intelektualitas adalah pembentukan dan pembinaan berfikir akademis dengan segala sesuatu yang bermanfaat; ilmu pengetahuan ilmiyah, peradaban, modernisme serta kesadaran berfikir dan berbudaya. 
Abd al-Rahman al-Nahlawi membagi secara garis besar tanggungjawab pendidik ke dalam dua bagian dengan merujuk kepada Al-Quran surat Ali Imran ayat 164 dan al-Baqarah ayat 129. la mengemukakan bahwa tanggungjawab pendidik adalah berupaya membersihkan, memelihara dan mengembangkan fitrah manusia. dia berkewajiban menyampaikan ilmu pengetahuan dan nilai-nilai bermanfaat lainnya agar peserta didik menerapkannya dalam kehidupan (alNahlawi:170).

Mencermati tugas dan fungsinya sebagai pendidik, maka tanggung jawab tenga pendidik memang begitu berat, terutama dalam tanggung jawabnya membentuk manusia yang beriman dan bertakwa, cerdas dan terampil serta mampu mandiri sehingga terwujud manusia yang sarat akan sumber daya dan kualitas (Hadi:18).

Di samping pembinaan intelektualitas, tenaga pendidik juga harus mampu mengarahkan peserta didik menyikapi berbagai perkembangan dan akselerasi kultural yang terjadi di sekitarnya. Tanggungjawab utama pendidik adalah membimbing anak didik atau peserta didik yang pada akhirnya mampu hidup dalam kemandirian, tidak tergantung kepada orang lain. kenapa hal ini perlu ditekankan? Karena perkembangan teknologi dan akselerasi sosial memacu dan mempengaruhi perkembangan individu dalam masyarakat serta membawa pengaruh besar pada norma dan sistem sosial masyarakat, perilaku, struktur keluarga, mobilitas masyarakat dan tingkat kompetensi (Hasan, 1994:201).

Bagaimana upaya para pendidik menumbuhkan kratifitas peserta didik, sehingga mereka menjadi dinamis dan produktif, tidak terlalu bergantung kepada orang tua atau pemerintah (ingin menjadi PNS).? Merupakan sebuah pertanyaan yang juga relatif sulit untuk dijawab, mengingat orientasi pendidikan kita saat ini lebih menekankan kepada pembentukan intelektualitas, bukan kepada kemandirian. Akibatnya terjadilah penganggura intelektual di mana-mana yang boleh jadi suatu saat menjadi "bom waktu" bagi pemerintah sebagai penanggungjawab pendidikan.

\section{PEMERINTAH}

Pemerintah merupakan penanggungjawab pendidikan atas dasar pertimbangan;

1) Pancasila yang berbunyi "keadilan sosial bagi seluruh rakyat Indonesia".

2) Bahwa pembukaan Undang-Undang Dasar Negara R.I than 1945 mengamanatkan agar pemerintah melindungi segenap bangsa dan seluruh tumpah darah Indonesia, memajukan kesejahteraan umum, mencerdaskan kehidupan bangsa dan ikut melaksanakan ketertiban dunia berdasarkan kemerdekaan, perdamaian abadi dan keadilan sosial.

3) Bahwa UUD 1945 mengamanatkan Pemerintah mengusahakan dan menyelenggarakan satu sistem pendidikan nasional yang bertujuan 
meningkatkan keimanan dan ketakwaan kepada Tuhan Yang Maha Esa serta akhlak mulia dalam rangka mencerdaskan kehidupan bangsa yang diatur dengan undang-undang.

4) Undang-Undang R.I Nomor 20 tahun 2003 tentang sistem Pendidikan Nasional (SISDIKNAS) yang berisi ketentuan dan ketetapan serta kebijakan pemerintah yang mengatur seluruh sistem dan komponen pendidikan yang paling terkait dan terpadu untuk mencapai tujuan pendidikan (Peraturan Pemerintah RI No. 20, 2003:1-3).

Atas dasar pertimbangan di atas, sebagai penanggungjawab pendidikan, maka pemerintah berkewajiban;

1. Menyediakan Infrastruktur Pendidikan yang meliputi;

a. Penyediaan sarana dan prasarana pendidikan

b. Penyediaan tenaga pendidik

c. Pengalokasian dana yang sesuai dengan kebutuhan

2. Melakukan Standarisasi Nasional terhadap pendidikan yang meliputi:
a. Proses
b. Kompetensi Lulusan
c. Tenaga Kependidikan
d. Evaluasi Pendidikan
e. Kurikulum Dasar

3. Membuat Peraturan Perundang-undangan yang disesuaikan dengan kebutuhan lokal maupun nasional, juga perbahan zaman, sebagai payung hukum berjalannya proses pendidikan.

\section{PENUTUP}

Pendidikan merupakan usaha sadar dan terencana untuk mewujudkan suasana belajar dan proses pembelajaran agar peserta didik secara aktif mengembangkan potensi dirinya untuk memiliki kekuatan spritual keagamaan, pengendalian diri, kepribadian, kecerdasaan, akhlak mulia serta keterampilan yang dibutuhkan bagi dirinya, masyarakat bangsa dan negara.

Ide tersebut di atas hanya akan terlaksana jika pendidikan benar-benar dilaksanakan dengan baik oleh mereka yang diamanatkan untuk mengembankan pendidikan tersebut antara lain; orang tua, pendidik, masyarakat dan pemerintah.

Kaitannya dengan tanggung jawab pendidikan, maka orang tua harus bertanggung jawab atas terselenggaranya pendidikan di rumah tangga, tenaga pendidik bertanggung jawab atas berlangsungnya pendidikan di sekolah/universitas dan pemerintah bertanggung jawab atas terlaksanakannya proses pendidikan secara nasional. 


\section{DAFTAR PUSTAKA}

Ahmad, Khursyid, Principle of Islamic Education, diterjemahkan oleh A.S. Robith dengan judul; Prinsip-Prinsip Pendidikan Islam, Surabaya: Pustaka Progressif, 1992.

Ali, Said Ismail, Nasy'at al-Tarbiyah al-Islamiyyah, Qahirah: Alim al-Kutub, 1978.

Ayyub, Hassan, al-Suluk al-ljtima'l fiy al-Islam, diterjemahkan oleh H. Sofyan dkk, dengan judul; Etika Islam, Bandung: Trigenda Karya, 1994.

Barmawi, Bakar Yusuf, Pembinaan Kehidupan Beragama Islam pada Anak-Anak Semarang: Dina Utama, 1993.

Daradjat, Zakiah, Kesehatan Mental, Jakarta: Gunung Agung, 1982. Pendidikan Agama dan Pembinaan Mental, Jakarta: Bulan Bintang, 1982.

Hasan, Khalija, Dimensi-Dimensi Psikologi Pendidikan, Surabaya: al-Ikhlas, 1994.

Ibnu Majah, Sunan Ibnu Majah, Juz II, Indonesia: Maktabah Dahlan, t.th.

Joni, T. Raka, "Kurikulum Pendidikan Dasar Menyongsong Abad Informasi”, Analisis CSIS, 1990.

Langgulung, Hasan, Manusia dan Pendidikan, Jakarta: Pustaka al-Husna, 1989.

Laporan Bank Dunia: Early Child Development in Indonesia, Jakarta: 1996.

Mastuki HS dan Moh. Irfan, Teologi Pendidikan: Tauhid Sebagai Paradigma Pendidikan Islam, Jakarta: Friska Agung Insani, 2001.

Muhaimin, Konsep Pendidikan Islam, Solo: Ramadhani, 1993.

Al-Nahlawi, Abd. Rahman, Usul al-Tarbiyah al-Islamiyyah WA Asalibuha, diterjemahkan oleh Sihabuddin dengan judul; Pendidikan Islam di Rumah, Sekolah dan Masyarakat, Jakarta: Gema Insani Press, 1995.

Nawawi, Hadari, Pendidikan dalam Islam, Surabaya: al-Ikhlas, 1993.

Peraturan Pemerintah RI. No. 20/2003 Tentang Undang-Undang Sistem Pendidikan Nasional, Bandung: Citra Umbara, 2003.

Qutb, Muhammad, Manhaj al-Tabiyah al-Islamiyyah, Beirut: Dar al-Syuruq, t.th.

Saifuddin, A.M. et.al, Desekularisasi Pemikiran Landasan Islam, Bandung: Mizan, 1987.

Tafsir, Ahmad, Pendidikan dalam Perspektif Islam, Bandung: Remaja Rosda Karya, 1992.

Taha, Khairiyah Husain, Daur al-Umm fiy Tarbiyah al-Atfal li al-Muslim, diterjemahkan oleh Hosen Arjaz dengan judul; Peran Ibu dalam Pendidikan Anak, Surabaya: Risalah Gusti, 1994. 
Ulwan, Abdullah Nasih, Tarbiyah al-Aulad fiy al-Islam, Juz I (Beirut: Dar al-Salam, 1981.

Umdirah, Abd. al-Rahman, Manhaj al-Qur'an fiy Tarbiyah al-Rijal, diterjemahkan oleh H. Abd. Hadi dengan judul; al-Qur'an dan Pendidikan Anak, Surabaya: Mutiara IImu, t.th. 